Harold Pinter 
Other Paperbacks in the Griffin Authors Series

GEOFFREY CHAUCER Edwin J. Howard

ANDRE GIDE Thomas Cordle

THOMAS HARDY Richard Carpenter

D. H. LAWRENCE RonaldP.Draper

PERCY BYSSHE SHELLEY Donald H. Reiman 


\section{Harold Pinter}

By Arnold P. Hinchliffe

University of Manchester 
(C) Twayne Publishers, Inc., 1967

All rights reserved. No part of this publication may be reproduced or transmitted, in any form or by any means, without permission

First published 1976 by

THE MACMILLAN PRESS LTD

London and Basingstoke

Associated companies in New York Dublin

Melbourne Johannesburg and Madras

SBN 333196511

ISBN 978-1-349-02953-2

ISBN 978-1-349-02951-8 (eBook)

DOI 10.1007/978-1-349-02951-8

This book is sold subject to the standard conditions of the Net Book Agreement.

The paperback edition of this book is sold subject to the condition that it shall not, by way of trade or otherwise, be lent, resold, hired out, or otherwise circulated without the publisher's prior consent, in any form of binding or cover other than that in which it is published and without a similar condition including this condition being imposed on the subsequent purchaser. 
To

MY MotherR 


\section{Preface}

In the preface to Experimental Drama, a symposium published in 1963, W. A. Armstrong explained the vitality of contemporary British drama as the meeting between imagination and complacency: “Beckett's enigmatic Godot has sent a religious tremor through a predominantly secular age: Pinter's haunted heroes have been a salutary reminder of what we still have to face when the Welfare State has done its best (or worst) for us: the tirades of Osborne's Jimmy Porter and the snide patter of his Archie Rice have emboldened the young and goaded their elders: Behan's Quare Fellow looms insistently over the issue of capital punishment: Bolt's Sir Thomas More, O'Casey's Father Ned, and Wesker's Beatie Bryant have likewise spoken to the conscience through the medium of the play."

Since 1956, it has been habitual to think of the British theater as once more vital and promising; whether or not the habit stemmed from an enthusiasm assumed by English critics as a relief from boredom and to assuage national pride (as George E. Wellwarth suggests in The Theater of Protest and Paradox), it is a habit that had so grown upon readers and critics alike that Bamber Gascoigne's 1964 New Year's article in The Observer, "Keeping Up with the Crisis," came as something of a shock. In it he reminded us that 1963 had produced not one new striking play: "The present score of dramatists seems to read: Osborne lost to films, Delaney silent, Behan indisposed, no full-length work from Pinter for over three years. Was it all a flash in a pan, the great new British drama?"1

In fact, Kenneth Tynan in Tynan on Theater (reprinted, 1963) had anticipated this view, and John Russell Taylor echoed it in Plays and Players (August, 1964) in an article entitled, "What's Happened to the New Dramatists?" A hiatus of this kind is certainly disturbing, but then, as Gascoigne pointed out, 1594 was also a bad year: Thomas Kyd was dead without living up to his promise; Christopher Marlowe had been killed in somewhat unsavory circumstances; and Robert Greene was dead of over- 
indulgence. Only William Shakespeare was left, a dramatist who had shown signs of promise but had then gone commercial by writing a huge star part for Richard Burbage in Richard III. It was encouraging to remember in the quatercentenary year of 1964 that 1594 had also seemed a black year for the British theater.

Of all the British dramatists who have emerged to produce this sense of a new, vital British theater, Harold Pinter seems to me the most interesting and significant. I hope the following pages will illustrate why I believe this to be so and will justify writing about a dramatist who is, I hope, only at the beginning of his career and who will continue to produce plays for the stage. It seems to me that the business of criticism is to dive in as soon as possible, especially when simple plays prove so apparently puzzling. Wellwarth has suggested that the very complexity of contemporary drama obliges critics to work at it while it is still alive-indeed, before it even comes to life-rather than wait to chart it as a movement in history. Such an obligation may exist, but my feeling is that the complexity as such is after the event, that an audience can enjoy Pinter immensely (if its reaction during performance is anything to go by) and only on leaving the charmed atmosphere of the auditorium does it qualify that enjoyment with the awful question: "But what did it mean?" As if, in fact, one or two hours of enjoyment do not themselves constitute a kind of meaning.

Terence Rattigan's reported exchange with Pinter is an example of this secondary response: "When I saw The Caretaker I told Pinter that I knew what it meant. 'It's about the God of the Old Testament, the God of the New, and Humanity, isn't it?" Pinter said blankly, 'No, Terry, it's about a caretaker and two brothers." "Similarly, when rehearsing the recent production of The Lover, Pinter is reported to have said: "We're not quite sure of the author's intention here." Neither of these cases rings untrue, nor, I am sure, are they examples of authorial perversity, either conscious or unconscious. In a radio interview with Laurence Kitchin, Pinter described his own running commentary on the plays as a complete waste of time. He has to come to his own plays objectively like anyone else: "I don't want to sound a mystificator, if there's a word, but I really do not know what ... is in the script from $A$ to $Z$ by any means. I think it would 


\section{Preface}

be an impertinence of me to say that I did ... as a director my function is really to look at the text quite independently and objectively really and truly and the only thing is I do of course ... happen to have something of the certain inner word. I mean someone. I know a little more. I've got something out of the horse's mouth. I've got a hot tip you know...."

Pinter has always insisted that his plays are simple and straightforward, and so they are until confronted with the question of specific meaning, by which people generally mean allegory. This book is partly the history of that particular question, partly a history of very recent British drama as Pinter has contributed to it, and partly a history of his personal development as a dramatist. It is also in many ways a history of a developing tolerance of his method. One of the remarkable things about his short career is the fact that within the space of five years or so, a dramatist who had been almost universally dismissed by drama critics is now accepted as one of the leading dramatists of the day. Laurence Kitchin sees him as the most accomplished dramatist of the 1960's so far, a view supported by John Russell Taylor. For Joseph Chiari, Pinter is more versatile and more gifted and is a better craftsman than any of his contemporaries and, with the possible exception of John Arden, is likely to outdistance all of them.

In 1964, John Russell Brown took another look at Shakespeare in the light of Pinter's plays. But not all critics are converted, of course. Allardyce Nicoll, in his revised British Drama (1962), included the Theater of the Absurd for the first time; he devoted six lines to N. F. Simpson, merely mentioned Pinter, and described Waiting for Godot as "the much-discussed and somewhat repetitively boring" play. Each critic is subject to personal taste, naturally; but when Nicoll described R. C. Sherrif's play The Long Sunset (1955) as thoughtful, it is clear that taste can restrict judgment too excessively. ${ }^{2}$

In short, Pinter has already produced enough that is interesting, significant, and well done to deserve some sort of critical attention, albeit of an elementary kind. This little history intends to be nothing more than an elementary introduction.

Harold Pinter is quintessentially the English (I am tempted to say "London") representative of Absurd Theater. $\mathrm{He}$ has incorporated the genre so successfully that it is almost parochial 
in flavor and looks decidedly home-grown. This ability to fuse European Absurdity with the English way of life, the foreign with the native, the timeless and universal with the immediate and local, gives Pinter's plays a lasting quality. He will remain one of Britain's most important twentieth-century dramatistsin my opinion, the most important.

Manchester, 1966

ArNold P. Hinchinfe 


\section{Acknowledgments}

I am deeply indebted to Harold Pinter, not merely for permission to use unpublished and broadcast material, but also for the interest he has shown in the work as it proceeded. I should also like to thank Joseph Losey and Warner Pathe (for help in connection with The Servant); Iain Hamilton (for sending me the first publication of "A Slight Ache"); Alan Hancox (for assistance in tracking down Pinter's poetry); Peter Wait and Methuen's for continued assistance with the published texts of Pinter; the Staff of the British Museum Reading Room (for research into the first publication of "The Examination"); and John Kershaw of A.T.V. Ltd., for the script of the Tempo program in October, 1965.

I must also thank Zdzislaw Mikulski for his translation of the article by Grzegorz Sinko, and Professor Sinko for permission to use the article, and my colleague F. N. Lees for permission to quote from his paper on Samuel Beckett.

I wish to acknowledge the part played by the work of Martin Esslin and John Russell Taylor, which far exceeds what is recorded in the footnotes, and that, in the opening chapter, I have been much influenced by Raymond Williams' essay on contemporary drama.

I also wish to thank David Hirst and Andrew P. Debicki, who have found texts and criticisms for me, and finally, John Davidson, who typed, corrected, retyped, and recorrected the text.

The following permissions to quote from and refer to published works are acknowledged:

From Stratford-on-Avon Studies, No. 4, edited by J. R. Brown and B. Harris, for chapters by Clifford Leech and R. D. Smith. Copyright (C) Edward Arnold (Publishers), Ltd.

From Experimental Drama, edited by W. A. Armstrong, for essays by W. A. Armstrong, Geoffrey Bullough and Martin Esslin. Copyright (C) 1963 by G. Bell and Sons, Ltd.

From The Dark Comedy, by J. L. Styan. Copyright (C) 1962 by Cambridge University Press. 
From "Mr. Pinter's Shakespeare," by John Russell Brown, by permission of the editor, Critical Quarterly, V. 3.

From The Theater of the Absurd, by Martin Esslin. Copyright (C) by Martin Esslin. Reprinted by permission of Doubleday \& Company, Inc.

From The Birthday Party, review by Irving Wardle in Encore (July-August, 1958), by permission of the editors.

From The Kitchen Sink, by G. Wilson Knight in Encounter (December, 1963), by permission of the editor.

From Mid-Century Drama, by Laurence Kitchin. Copyright (C) by Faber and Faber, Ltd.

From "Joseph Losey and The Servant," by Jacques Brunius in Film, 38, by permission of the editor.

From "The Theater of the Absurd-How Absurd?" by David Tutaev in Gambit, by permission of the editor.

From Twentieth Century Drama, by Bamber Gascoigne. Copyright (C) by The Hutchinson Publishing Company.

From the plays of Harold Pinter. Copyright (C) Harold Pinter. Reprinted by permission of Grove Press, Inc., and Methuen \& Co., Ltd.

From Anger and After, by John Russell Taylor. Copyright (C) by John Russell Taylor, reprinted by permission of Methuen \& Co., Ltd.

From Modern Drama, for the articles by J. T. Boulton, "Harold Pinter: The Caretaker and Other Plays" (September, 1963), and J. Hoefer, "Pinter and Whiting: Two Attitudes Towards the Alienated Artist" (February, 1962), by permission of the editor.

From New Theater Magazine, for the article by Harold Pinter, "Harold Pinter Replies" (January, 1961), and the John Arden review of The Caretaker (July, 1960), by permission of the editor.

From The Theater of Protest and Paradox, by G. E. Wellwarth. Copyright (C) by New York University Press.

From New English Dramatists, No. 3, by J. W. Lambert, by permission of Penguin Books, Ltd.

From Nausea, by Jean-Paul Sartre, translated by Lloyd Alexander, by permission of the publishers, New Directions.

From Sexual Deviations, by Anthony Storr, by permission of Penguin Books, Ltd. 


\section{Acknowledgments}

From an interview on filming The Caretaker in Transatlantic Review, No. 13, by permission of the editor.

From Tulane Drama Review, for articles by Ruby Cohn, "The World of Harold Pinter" (March, 1962), and Bernard Dukore, "The Theater of Harold Pinter" (March, 1962), by permission of the editor.

From Twentieth Century, for "Writing for Myself," by permission of Harold Pinter and the editor.

From Existentialism from Dostoevsky to Sartre, by Walter Kaufmann. Copyright (C) by The World Publishing Company.

From Sartre, by Iris Murdoch. By permission of Yale University Press. 


\section{Contents}

Preface

Acknowledgments

Chronology 17

1. The New Theater 21

2. Comedies of Menace 38

3. The Caretaker 87

4. Plays for Television 108

5. Interim Report 125

6. The Homecoming 146

7. Conclusion 163

Notes and References 166

Selected Bibliography 176

Index $\quad 185$ 


\section{Chronology}

1930 Harold Pinter born in Hackney, London; only child of Jewish parents. Educated at Hackney Downs Grammar School. Entered Royal Academy of Dramatic Art, but finally faked nervous breakdown and left. Two trials as conscientious objector.

1949- Repertory actor under the name of David Baron; spent

1957 eighteen months with McMaster's company in Ireland.

1956 Married Vivien Merchant.

1957 The Room, The Birthday Party, and The Dumb Waiter written.

1957- Bristol University productions of The Room. Cambridge

1958 Arts Theatre production of The Birthday Party, which later ran for less than a week at the Lyric Theatre, Hammersmith.

1959 A Slight Ache, British Broadcasting Corporation, "Third Program," July 29th. "The Examination," published in Prospect (Summer, 1959). Pieces of Eight, Apollo Theatre, London, September 3rd, contained: "Getting Acquainted," "Request Stop," "Special Offer," and "Last to Go." One to Another, Lyric Opera House, Hammersmith, transferred to the Apollo Theatre, contained: "The Black and White" and "Trouble in the Works."

1960 The Room and The Dumb Waiter (first performed at Frankfurt Municipal Theatre) produced at Hampstead Theatre Club, January 21st, and later in March at the Royal Court Theatre. A Night Out, British Broadcasting Corporation, "Third Program," March 1st, and Independent Television Authority, April 24th. The Caretaker, Arts Theatre, London, April 27th, and the Duchess Theatre on May 30th. Night School, Independent Television Authority, July 21st. The Dwarfs, British Broadcasting Corporation, "Third Program," December 2nd.

1961 A Slight Ache, Arts Theatre, January 18th. The Collection, Independent Television Authority, May 11th. 
1962 The Collection, Aldwych Theater, June 18th.

1963 The Caretaker, filmed in Hackney. The Lover, Independent Television Authority, March 28th. The Lover and The Dwarfs, Arts Theatre, London, September 16th. "The Examination," republished with The Lover and The Collection. "Dialogue for Three," Stand, Vol. VI, No. 3 (n.d.). Script for the film The Servant directed by Joseph Losey. Script for The Pumpkin Eater directed by Jack Clayton. Script for film not yet produced, The Compartment. Short story "Tea Party" broadcast British Broadcasting Corporation in 1964.

1964 New sketches broadcast, British Broadcasting Corporation, "Third Program."

1965 Tea Party, March 25th, British Broadcasting Corporation Television (and throughout Europe). The Homecoming, Cardiff, March 26th, presented by the Royal Shakespeare Company.

1968 Awarded C.B.E. Birthday Honours List. Script for The Quiller Memorandum, directed by Michael Anderson; script for Accident, directed by Joseph Losey.

1967 The Basement (originally film-script entitled The Compartment) February 20th. British Broadcasting Corporation Television Channel 2. Received Antoinette Perry Award for The Homecoming, the best Broadway Drama of 1966. 


\section{Harold Pinter}

